\title{
Review
}

\section{Applications of three-dimensional printers in prosthetic dentistry}

\author{
Hidemichi Kihara $^{1)}$, Shiho Sugawara ${ }^{1)}$, Jun Yokota ${ }^{1}$, Kyoko Takafuji ${ }^{1)}$, Shota Fukazawa ${ }^{1)}$, Ayaka Tamada ${ }^{2)}$, \\ Wataru Hatakeyama ${ }^{1}$, and Hisatomo Kondo ${ }^{1)}$
}

1) Department of Prosthodontics and Oral Implantology, School of Dentistry, Iwate Medical University, Morioka, Japan

${ }^{2}$ Department of Dysphagia Rehabilitation, Nagasaki University Hospital, Nagasaki, Japan

(Received February 13, 2021; Accepted April 12, 2021)

\begin{abstract}
This narrative review aims to provide an overview of recent studies and case reports on three-dimensional (3D) printing, and to verify the applicability of $3 \mathrm{D}$ printers in the field of dental prostheses. This review was performed by conducting a search of PubMed. The clinical application of fabricating a prosthesis made with cobalt-chromium is considered possible depending on the material and hardware of the $3 \mathrm{D}$ printer. However, it is currently difficult to assess the clinical use of 3D-printed zirconia crowns. Further research is required, such as verification of materials used, margin morphology, and hardware. Clinically acceptable results have been reported for patterns using 3D printers. Interim restorations made using a $3 \mathrm{D}$ printer have been reported with good results that are considered clinically usable. Dentures made with 3D printers need further verification in terms of strength and deformation. Custom trays made with 3D printers are clinically useful, however, issues remain with design time and effort. Although several studies have reported the usefulness of 3D printers, further verification is required since $3 \mathrm{D}$ printers are still considered new technology.
\end{abstract}

Keywords; digital dentistry, three-dimensional printed crown, threedimensional printed removable denture, three-dimensional printing

\section{Introduction}

Three-dimensional (3D) printing technology was developed in the 1980s. Initially, applications were limited due to issues such as product strength, accuracy, processing speed, and cost. However, research and development has proceeded around the world to produce real products using 3D printing. Currently, 3D printing is being utilized in the manufacture of various products due to improvements in processing accuracy and diversification of laminated materials [1]. In the field of dentistry, prostheses manufactured by $3 \mathrm{D}$ printers have a degree of freedom in design, and are considered to have a lot of potential. Digital dentistry was first used in the 1980s, and started with an attempt to make a dental prosthesis using a computer aided design/computer aided manufacturing (CAD/CAM) system [2-8]. The milling system used in dentistry, appeared in 1980 and was characterized by allowing ceramic inlays to be manufactured on the day cavities were treated [9-13]. The treatment was completed on the same day the inlay cavity was prepared, and it became the forerunner of the so-called sameday prosthesis. Since 2013, many papers (such as original articles, case reports, and reviews) on 3D printers in the dental field have been published (Fig. 1). At this stage, 3D printers were validated by making bone casts for oral surgical procedures [14-17], casts for simulating implant placement, and surgical templates for implant placement $[18,19]$.

More recently, a technology known as 3D bioprinting, which allows the printing of cells and scaffolds together (biomaterials containing cells) or of cell aggregates without scaffolds, has been developed [20-23]. Furthermore, 3D bioprinting has permitted a wide range of materials with proven

Correspondence to Dr. Hidemichi Kihara, Department of Prosthodontics and Oral Implantology, School of Dentistry, Iwate Medical University, 19-1 Uchimaru, Morioka, Iwate 020-8505, Japan Fax: +81-19-652-3820 E-mail: hkihara@iwate-med.ac.jp

J-STAGE Advance Publication: June 2, 2021

doi.org/10.2334/josnusd.21-0072

DN/JST.JSTAGE/josnusd/21-0072 osteoinductive capacity such as polycaprolactone, ceramic bases, calcium phosphate injectable pastes, and cell-laden hydrogels to be printed, although the printing still depends on the materials and methods as well as the capabilities of the printer hardware [24-28].

In terms of accuracy for manufacturing prosthetic devices, many studies have reported that the milling system has sufficient performance to manufacture dental prostheses [29-34]. In contrast, 3D printers are capable of forming complex shapes such as hollow interiors that were previously impossible with the milling system, and the capability could be considered as an advancement in reducing the weight of prostheses. In terms of consumption of materials, the milling system tends to waste materials because it cuts out large blocks when molding shapes. In this respect as well, 3D printers are considered economical as there is no excess material.

This review validated recent studies and case reports on $3 \mathrm{D}$ printing using a PubMed search, and considered the applicability of 3D printers in the field of dental prostheses.

\section{Materials and Methods}

This review was based on articles searched via the PubMed database and the period for the search was from June 1, 2020 to November 30, 2020. The reviewed articles were published between 2013 and 2020. The search keywords were " $3 \mathrm{D}$ printing, three dimensional printing, crown, cast pattern, tray, denture, superstructure", and different combinations of the keywords were used during the search.

\section{Results}

\section{D-printed master cast for definitive prosthesis}

Applications of $3 \mathrm{D}$ printers for the production of fixed prostheses have been reported in the literature on production of master casts. Some studies (Table 1) evaluated master casts produced by a 3D printer and those made using a conventional superimposition method [35-37]. Two studies validated crowns, bridges, and inlays using 3D-printed casts [36,37], and the other one dealt only with crowns [35]. The three studies showed that master casts produced by the conventional method using gypsum and silicone elastomeric impression material were significantly more accurate than the casts made by a $3 \mathrm{D}$ printer. In the present circumstances, it is considered difficult to make a cast for a definitive prosthesis using a $3 \mathrm{D}$ printer. However, if it is possible to produce a highly accurate master cast that can be applied clinically using a 3D printer in the future, the master cast may be more useful than a milled master cast in terms of materials that can only be used in $3 \mathrm{D}$ printers and reduction of material consumption due to hollowing of the inside.

\section{D-printed prosthesis}

Studies on the accuracy of prostheses produced by $3 \mathrm{D}$ printers are shown in (Table 2). A zirconia crown manufactured by a 3D printer was reported and its accuracy was verified [38,39]. In one of the above studies, 3D-printed zirconia crowns were evaluated for their internal and marginal adaptation [39]. The authors found that internal and marginal adaptation is not yet satisfactory for clinical application. Wang et al. evaluated crowns that were processed either with a 3D printing system or with a dental milling system, with the crowns being scanned using a dental laboratory scanner [38]. The study concluded that zirconia crowns produced by $3 \mathrm{D}$ printing meet the trueness requirements, and $3 \mathrm{D}$ printing may be suitable for fabricating zir- 


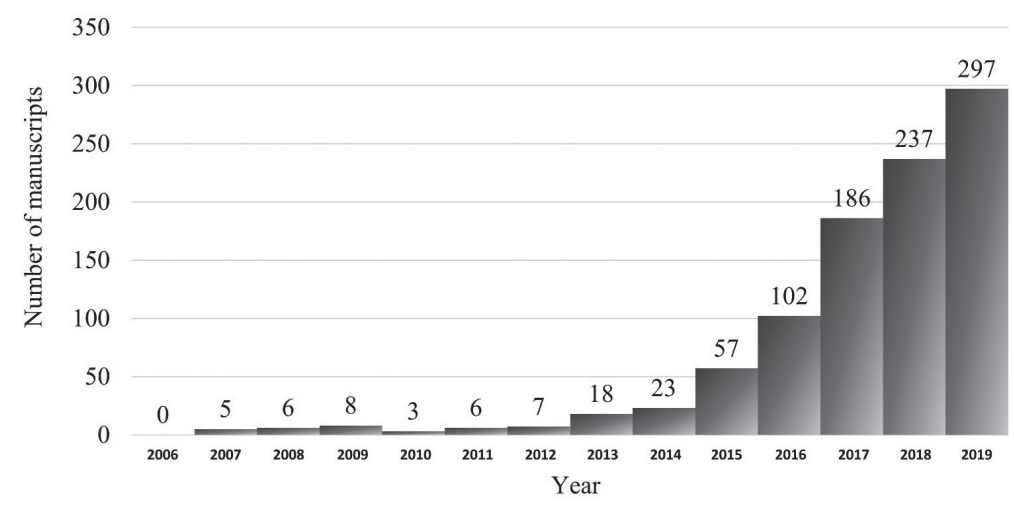

Fig. 1 The number of 3D printer manuscripts published each year

Table 1 Studies evaluating master casts

\begin{tabular}{llll}
\hline First author, year, [Ref.] & Product by 3D printer & Evaluation method & Result \\
\hline Jang Y, 2018, [35] & Master cast & Evaluation by superimposing crowns & $\begin{array}{l}\text { Although the fit of crowns fabricated based on the 3D printed models was inferior } \\
\text { to that of crowns prepared with the conventional stone die group, values obtained } \\
\text { with the 3D printing group were in the clinically acceptable range }(<120 \mu \mathrm{m}) .\end{array}$ \\
Sim JY, 2019, [36] & Master cast & Evaluation by superimposing the master cast & $\begin{array}{l}\text { There was no significant difference in accuracy between the plaster model and the } \\
\text { digital model. However, the accuracy of the models made with 3D printers was low } \\
\text { when compared with the stone model. }\end{array}$ \\
Choi JW, 2019, [37] & Master cast & Evaluation by superimposing the master cast & Conventional gypsum models showed better accuracy than 3D printed models. \\
\hline
\end{tabular}

conia crowns. Zirconia crowns made with 3D printers have received little attention, so it is not possible to determine whether 3D-printed zirconia crowns are in clinical use. However, future technological developments may lead to the clinical application of 3D-printed zirconia crowns.

In 2019, accuracy of crowns for upper molars manufactured by a conventional method (i.e. lost-wax casting), 3D printer, and milling system, was verified using $10 \mathrm{Co}-\mathrm{Cr}-\mathrm{Mo}$ metal [40]. The margin gap was measured, and that produced by casting had a smaller gap than the one produced by milling system or 3D printer. However, no significant difference was found between the milled crown and the 3D-printed crown. The authors concluded that crowns made using these three methods were clinically acceptable. In studies that verified the accuracy of prostheses using a 3D printer, a large number of studies using cobalt-chromium were reported (Table 2). Many studies reported them to be clinically acceptable and/or better than milling [40-48]. Only two studies stated that they were clinically unacceptable $[49,50]$.

From these studies, the clinical application of cobalt-chromium is considered possible depending on the material and hardware of the $3 \mathrm{D}$ printer. However, lack of research makes it difficult to assess the clinical application of zirconia. Additionally, it will be necessary to search for the best overall method such as materials to be used by the 3D printer to make the final prosthesis, shape of the margins, and printer hardware. Further verification is needed in the future.

\section{D-printed pattern for fixed dental prosthesis}

The effectiveness of a fixed dental prosthesis using a pattern made by a 3D printer has been reported. A recent study reported that patterns of lithium disilicate for press were produced using three different methods, that is, by using 3D printers, milling, and conventional methods, where prostheses were produced using patterns, and that their effectiveness was verified [51]. All three patterns were found to be clinically acceptable. In addition, research in 2019 confirmed the accuracy of fixed dental prostheses cast using a wax pattern produced with a 3D printer [52]. This paper concluded that the pattern produced by the 3D printer was clinically acceptable and had a better marginal fit than the pattern produced by milling. Although it cannot be ascertained because the number of studies is small, it seems that pattern production using a $3 \mathrm{D}$ printer is clinically acceptable.

\section{D-printed interim restoration}

Several papers have documented the production of interim restorations with 3D printers (Table 3) [53-58]. In 2017, interim restorations were manufactured with a milling machine and a 3D printer to verify them [55]. The authors concluded that the restorations produced by both methods had the same accuracy. In addition, the paper indicated that the finish line morphology had a significant impact on accuracy.

Another study in 2018 also reported that interim restorations made with a 3D printer were clinically acceptable [56]. Also, in a study verified by a silicone replica method, when comparing interim restorations made with milling and by a $3 \mathrm{D}$ printer, it was found that the one produced by $3 \mathrm{D}$ printer was superior to milling in verifying marginal fit [53]. Other research that validated the internal fit of a interim restoration also reported that the interim restoration of a $3 \mathrm{D}$ printer was a better fit than the interim restoration made by a conventional wax-up method [58]. A study in 2017 verified the material properties of interim restoration produced by $3 \mathrm{D}$ printers [57]. In conclusion, it was suggested that 3D-printed interim restorations would allow sufficient mechanical properties for oral use.

From the findings of this research, the production of interim restoration with $3 \mathrm{D}$ printers is considered to be sufficient for clinical application. However, it is considered that the present superiority is not recognized when compared with interim restoration produced by milling system.

If it is possible to manufacture a interim restoration by $3 \mathrm{D}$ printer at a lower price and higher strength than one produced by the milling system, the versatility of using interim restorations made by $3 \mathrm{D}$ printing may be further expanded.

\section{D printers for manufacturing removable dentures}

Regarding studies on applications of 3D printers for manufacturing dentures, it was reported that a casting metal framework made by a pattern with a 3D printer was compared with a metal framework using a conventional wax pattern, and the accuracy of metal frameworks or denture bases made directly by the 3D printer was compared with the conventional method. In 2019, research evaluating metal frameworks for partial dentures using a $3 \mathrm{D}$ printer was reported $[59,60]$. In a study verifying the accuracy of metal frameworks by 3D printing, it was concluded that the metal frames manufactured by $3 \mathrm{D}$ printing had better manufacturing accuracy and reproducibility than those manufactured by lost-wax casting [60]. In another study, a metal framework produced by 3D printing had clinically applicable indications, but a frame produced by casting was still slightly superior [59]. In research on the accuracy of denture bases made with 3D printers, the authors compared conventional denture bases made by heat-activated polymerization with 3D-printed ones, and examined their accuracy [61]. The result of this study was that denture bases made with 3D printers were 
Table 2 Studies evaluating 3D printed prostheses

\begin{tabular}{|c|c|c|c|c|}
\hline $\begin{array}{l}\text { First author, year, } \\
\text { [Ref.] }\end{array}$ & $\begin{array}{l}\text { Product by 3D } \\
\text { printer }\end{array}$ & Printing technology & Evaluation method & Result \\
\hline $\begin{array}{l}\text { Wang W, 2019, } \\
{[38]}\end{array}$ & Zirconia crown & Stereolithography & $\begin{array}{l}\text { The crowns scanned using a dental } \\
\text { laboratory scanner }\end{array}$ & $\begin{array}{l}\text { The trueness of the external surface of the 3D printed zirconia crowns was no } \\
\text { worse than the corresponding trueness of the CAD-CAM crowns. }\end{array}$ \\
\hline Li R, 2019, [39] & Zirconia crown & Stereolithography & $\begin{array}{l}\text { The measured cement space of 3D } \\
\text { printed zirconia crown }\end{array}$ & $\begin{array}{l}\text { Internal and marginal adaptation of stereolithography-manufactured zirconia } \\
\text { was not yet suitable for clinical application. }\end{array}$ \\
\hline $\begin{array}{l}\text { Chang HS, 2019, } \\
{[40]}\end{array}$ & $\begin{array}{l}\text { Co-Cr-Mo metal } \\
\text { crowns }\end{array}$ & $\begin{array}{l}\text { Selective laser } \\
\text { sintering }\end{array}$ & $\begin{array}{l}\text { The marginal gaps calculated } \\
\text { using a 3D replica and mapping } \\
\text { technique }\end{array}$ & $\begin{array}{l}\text { The conventional lost wax and casting method had better accuracy in mar- } \\
\text { ginal gap than the 3D printing method, but the 3D printed crown was still } \\
\text { applicable to dental restorations. }\end{array}$ \\
\hline $\begin{array}{l}\text { V Harish, 2014, } \\
\text { [41] }\end{array}$ & Co-Cr copings & Laser sintering & $\begin{array}{l}\text { Compared to the internal and } \\
\text { marginal fit }\end{array}$ & $\begin{array}{l}\text { The copings fabricated by Laser sintering technique showed better internal } \\
\text { and marginal fit than the copings fabricated by the conventional casting } \\
\text { technique. }\end{array}$ \\
\hline $\begin{array}{l}\text { Sundar MK, 2014, } \\
{[42]}\end{array}$ & Co-Cr copings & Laser sintering & $\begin{array}{l}\text { Compared to the marginal fit and } \\
\text { microleakage }\end{array}$ & $\begin{array}{l}\text { The copings fabricated using metal laser sintering technique had a better } \\
\text { marginal fit and an observable decrease in microleakage when compared to } \\
\text { the copings fabricated using the conventional lost wax technique. }\end{array}$ \\
\hline $\begin{array}{l}\text { Park JK, 2015, } \\
{[43]}\end{array}$ & Metal copings & $\begin{array}{l}\text { Direct laser metal } \\
\text { sinterization } \\
\text { (DLMS) }\end{array}$ & $\begin{array}{l}\text { To assess the marginal and internal } \\
\text { gaps of the copings }\end{array}$ & $\begin{array}{l}\text { The coping produced by conventional casting had significantly better results } \\
\text { than milling and DLMS, but the copings fabricated by computer-aided mill- } \\
\text { ing and DLMS fell within the range of clinical acceptance. }\end{array}$ \\
\hline $\begin{array}{l}\text { Huang Z, 2015, } \\
{[44]}\end{array}$ & Single-unit crowns & $\begin{array}{l}\text { Selective laser } \\
\text { sintering (SLS) }\end{array}$ & $\begin{array}{l}\text { Compared to the marginal and } \\
\text { internal fit of single-unit crowns }\end{array}$ & $\begin{array}{l}\text { The SLS system demonstrated better marginal and internal fit compared to } \\
\text { the milling systems. }\end{array}$ \\
\hline $\begin{array}{l}\text { Ates SM, 2016, } \\
{[45]}\end{array}$ & Metal frameworks & $\begin{array}{l}\text { Direct laser metal } \\
\text { sinterization } \\
\text { (DLMS) }\end{array}$ & $\begin{array}{l}\text { Evaluation of the marginal fit of } \\
\text { frameworks and marginal gap } \\
\text { values using a stereomicroscope }\end{array}$ & $\begin{array}{l}\text { As an alternative milling technique, the DLMS technique exhibited satis- } \\
\text { factory results and this CAD-CAM technique will become widely used in } \\
\text { dentistry. }\end{array}$ \\
\hline $\begin{array}{l}\text { Gunsoy S, 2016, } \\
{[46]}\end{array}$ & Co-Cr crowns & $\begin{array}{l}\text { Direct laser metal } \\
\text { sinterization } \\
\text { (DLMS) }\end{array}$ & Evaluation of marginal/internal fit & $\begin{array}{l}\text { Additive manufacturing crown performed better than milling one, but the } \\
\text { CAD-CAM techniques did not exceed the conventional procedure with lost- } \\
\text { wax and metal casting in the hands of an experienced dental technician. }\end{array}$ \\
\hline $\begin{array}{l}\text { Dahl BE, 2017, } \\
{[47]}\end{array}$ & $\begin{array}{l}\text { Single crowns } \\
\text { with laser-sintered } \\
\text { Co-Cr }\end{array}$ & Laser sintering & $\begin{array}{l}\text { To verify internal fit (Measuring } \\
\text { cement space using specifically } \\
\text { designed computer software) }\end{array}$ & $\begin{array}{l}\text { Additive manufacturing crown performed better than milling one, but the } \\
\text { CAD-CAM techniques did not exceed the conventional procedure with lost- } \\
\text { wax and metal casting in the hands of an experienced dental technician. }\end{array}$ \\
\hline $\begin{array}{l}\text { Lovgren N , 2017, } \\
{[48]}\end{array}$ & $\begin{array}{l}\text { Co-Cr single } \\
\text { crowns }\end{array}$ & Laser sintering & $\begin{array}{l}\text { Compared the marginal and } \\
\text { internal fit }\end{array}$ & $\begin{array}{l}\text { Laser-sintered Co-Cr crown copings showed increased surface roughness and } \\
\text { better internal and marginal fit than copings produced by milling or milled } \\
\text { wax/lost wax technique. }\end{array}$ \\
\hline $\begin{array}{l}\text { Kim KB, 2013, } \\
{[49]}\end{array}$ & $\begin{array}{l}\text { Co-Cr three-unit } \\
\text { fixed dental } \\
\text { prostheses }\end{array}$ & $\begin{array}{l}\text { Direct laser metal } \\
\text { sinterization } \\
\text { (DLMS) }\end{array}$ & $\begin{array}{l}\text { Examined marginal fit using a } \\
\text { light-body silicone }\end{array}$ & $\begin{array}{l}\text { The marginal fit of the DLMS system appeared significantly inferior com- } \\
\text { pared to that of the conventional lost wax technique method. }\end{array}$ \\
\hline $\begin{array}{l}\text { Nesse H, 2015, } \\
{[50]}\end{array}$ & Co-Cr restorations & $\begin{array}{l}\text { Selective laser } \\
\text { sintering (SLS) }\end{array}$ & $\begin{array}{l}\text { Internal fit measuring with the } \\
\text { replica method }\end{array}$ & $\begin{array}{l}\text { SLS restorations had the worst internal and marginal fit comparing to casting } \\
\text { and milling system. }\end{array}$ \\
\hline
\end{tabular}

Table 3 Studies evaluating 3D printed interim restorations

\begin{tabular}{|c|c|c|c|}
\hline First author, year, [Ref.] & Printing technology & Evaluation method & Result \\
\hline Lee WS, 2017, [53] & $\begin{array}{l}\text { Polyjet method and } \\
\text { stereolithography }\end{array}$ & $\begin{array}{l}\text { Internal discrepancy measurement } \\
\text { using the silicon replica method }\end{array}$ & $\begin{array}{l}\text { The marginal and internal fit of the interim restoration has more outstanding } 3 \mathrm{D} \\
\text { printing method than the CAD/CAM milling method. }\end{array}$ \\
\hline Mai HN, 2017, [54] & $\begin{array}{l}\text { Photopolymer-jetting 3D } \\
\text { printing }\end{array}$ & $\begin{array}{l}\text { To evaluate the fit of interim crowns } \\
\text { using the image-superimposition and } \\
\text { silicone-replica techniques }\end{array}$ & $\begin{array}{l}\text { Photopolymer-jetting 3D printing significantly enhanced the fit of interim } \\
\text { crowns, particularly in the occlusal region. }\end{array}$ \\
\hline Alharbi N, 2018, [55] & Stereolithography & $\begin{array}{l}\text { Scan of the mean gaps between the } \\
\text { master die and interim restorations } \\
\text { by micro-CT }\end{array}$ & $\begin{array}{l}\text { 3D printed interim restorations exhibit lower marginal and internal gaps than } \\
\text { milled restorations. }\end{array}$ \\
\hline $\begin{array}{l}\text { Molinero-Mourelle P, 2018, } \\
\text { [56] }\end{array}$ & $\begin{array}{l}\text { Double jet printing } \\
\text { (fused deposition modeling) }\end{array}$ & To measure the marginal fit & The marginal fit of $3 \mathrm{D}$ printed interim restorations was clinically acceptable. \\
\hline Tahayeri A, 2018, [57] & Stereolithography & To evaluate the mechanical property & $\begin{array}{l}\text { The results suggest that a } 3 \mathrm{D} \text { printable interim restorative material allows for } \\
\text { sufficient mechanical properties for intraoral use. }\end{array}$ \\
\hline Chaturvedi S, 2020, [58] & Stereolithography & $\begin{array}{l}\text { To evaluate marginal and internal fit } \\
\text { by measuring gaps using a scanning } \\
\text { electron microscope }\end{array}$ & $\begin{array}{l}\text { 3D printed interim restorations have better marginal and internal fit compared to } \\
\text { milled and molded interim restorations. }\end{array}$ \\
\hline
\end{tabular}

more accurate and had a greater retentive force than conventional denture bases. In 2019, the study examined the flexural bond strength between denture-based resins (heat cured one, milled one, and 3D-printed one) and commercially available denture teeth. In this study, teeth bonded to milling denture base and 3D-printed one showed significantly lower bond strength compared to a heat cured one [62].

Considering these results, it is thought that metal frameworks and denture bases can be used clinically on a research basis. However, issues remain with regard to the bonding of artificial teeth to denture bases made with 3D printers. Additionally, it is necessary to verify the strength, deformation, and long-term prognosis of the tip in the undercut area of the clasp produced by $3 \mathrm{D}$ printers.

\section{D printing custom tray for manufacturing dental prosthesis}

There have been a number of studies on verification of custom trays made with $3 \mathrm{D}$ printing. In a study that verified the accuracy of 3D-printed custom trays to obtain a precise impression of full-arch implant rehabilitation, it was reported that deviation in the position of the implant on the precision 
cast was significantly less in the custom tray made by 3D printing [63]. Several studies have validated 3D-printed custom trays for totally edentulous cases $[64,65]$. In the literature searched in this review, 3D-printed custom trays for edentulous patients were reported to be better than conventional methods. In 2020, a study verified the adhesive strength of the impression material on 3D-printed custom trays. It concluded that polylactide tray materials may be recommended for the most severe impressions [66]. In conclusion, custom trays made by $3 \mathrm{D}$ printing are suitable for more precise impression taking than conventional custom trays, when considering that that the adhesive strength of the impression material is maintained and the thickness of the impression material is uniform.

\section{Discussion}

There is no doubt that 3D printers will have a major impact on the dental field in the future. In this review, we looked at the prosthetic applications for 3D printers, but a limitation of this work is that many studies using 3D printers are not included. Many studies related to 3D printers remain to be validated. In the future, more detailed reviews will be needed in this area.

The following is a summary of this review of 3D printing: in the present circumstances, it is difficult to make a cast for a definitive prosthesis using a $3 \mathrm{D}$ printer; in relation to fabricating prostheses by $3 \mathrm{D}$ printer, it is considered the clinical application of cobalt-chromium is possible depending on the material and hardware of the 3D printer and that the clinical use of zirconia is difficult to assess. Further research is needed, such as verification of materials used, margin morphology, and hardware; clinically acceptable results have been reported for patterns using $3 \mathrm{D}$ printers, and if even better results are reported, general clinical application is considered possible; interim restorations made using a $3 \mathrm{D}$ printer have been reported with good results and are considered to be clinically usable; dentures made with 3D printers have a problem bonding between 3D-printed denture base and denture tooth, and need further verification in terms of strength and deformation; custom trays made with 3D printers are clinically useful, however, issues remain with design time and effort.

\section{Conflict of interest}

The authors declare no conflict of interest.

\section{References}

1. Berman B (2012) 3-D printing: The new industrial revolution. Business Horizons 55, 155162.

2. Rekow D (1987) Computer-aided design and manufacturing in dentistry: a review of the state of the art. J Prosthet Dent 58, 512-516.

3. Duret F, Blouin JL, Duret B (1988) CAD-CAM in dentistry. J Am Dent Assoc 117, 715720 .

4. Leinfelder KF, Isenberg BP, Essig ME (1989) A new method for generating ceramic restorations: a CAD-CAM system. J Am Dent Assoc 118, 703-707.

5. Mormann WH, Brandestini M, Lutz F, Barbakow F (1989) Chairside computer-aided direct ceramic inlays. Quintessence Int 20,329-339.

6. Rekow ED (1991) Dental CAD-CAM systems. What is the state of the art? J Am Dent Assoc 122, 42-48.

7. Mormann W, Krejci I (1992) Computer-designed inlays after 5 years in situ: clinical performance and scanning electron microscopic evaluation. Quintessence Int 23, 109-115.

8. van der Zel JM (1993) Ceramic-fused-to-metal restorations with a new CAD-CAM system. Quintessence Int 24, 769-778.

9. Smith BG, Cardwell JE (1989) One visit ceramic restorations made at the chairside: the cerec machine. Restorative Dent 5, 60-65.

10. Markowski A (1990) A CAD-CAM ceramic inlay technique. J Esthet Dent 2, 170-176.

11. Mormann WH, Brandestini M, Lutz F, Barbakow F, Gotsch T (1990) CAD-CAM ceramic inlays and onlays: a case report after 3 years in place. J Am Dent Assoc 120, 517-520.

12. Mormann WH, Curilović Z (1991) CEREC(R) CAD-CAM ceramic restorations. A case report after 5 years in place. Acta Stomatol Croat 25, 3-10.

13. Isenberg BP, Essig ME, Leinfelder KF (1992) Three-year clinical evaluation of CAD/CAM restorations. J Esthet Dent 4, 173-176.

14. Cohen A, Laviv A, Berman P, Nashef R, Abu-Tair J (2014) Mandibular reconstruction using stereolithographic 3-dimensional printing modeling technology. Oral Surg Oral Med Oral Pathol Oral Radiol Endod 108, 661-666.

15. Palhazi P, Nemes B, Swennen G, Nagy K (2014) Three-dimensional simulation of the nasoalveolar cleft defect. Cleft Palate Craniofac J 51, 593-596.

16. Cousley RR, Turner MJ (2014) Digital model planning and computerized fabrication of orthognathic surgery wafers. J Orthod 41, 38-45.

17. Ayoub AF, Rehab M, O'Neil M, Khambay B, Ju X, Barbenel J et al. (2014) A novel approach for planning orthognathic surgery: The integration of dental casts into threedimensional printed mandibular models. Int J Oral Maxillofac Surg 43, 454-459.

18. Schepers RH, Raghoebar GM, Vissink A, Lahoda LU, Van der Meer WJ, Roodenburg JL et al. (2013) Fully 3-dimensional digitally planned reconstruction of a mandible with a free vascularized fibula and immediate placement of an implant-supported prosthetic construction. Head Neck 35, E109-114.
19. Flugge TV, Nelson K, Schmelzeisen R, Metzger MC (2013) Three-dimensional plotting and printing of an implant drilling guide: simplifying guided implant surgery. J Oral Maxillofac Surg 71, 1340-1346.

20. Obregon F, Vaquette C, Ivanovski S, Hutmacher DW, Bertassoni LE (2015) Three-dimensional bioprinting for regenerative dentistry and craniofacial tissue engineering. J Dent Res 94, 143S-152S.

21. Athirasala A, Tahayeri A, Thrivikraman G, Franca CM, Monteiro N, Tran V et al. (2018) A dentin-derived hydrogel bioink for $3 \mathrm{D}$ bioprinting of cell laden scaffolds for regenerative dentistry. Biofabrication 10, 024101.

22. Ma Y, Xie L, Yang B, Tian W (2019) Three-dimensional printing biotechnology for the regeneration of the tooth and tooth-supporting tissues. Biotechnol Bioeng 116, 452-468.

23. Thattaruparambil Raveendran N, Vaquette C, Meinert C, Samuel Ipe D, Ivanovski S (2019) Optimization of 3D bioprinting of periodontal ligament cells. Dent Mater 35, 1683-1694.

24. Inzana JA, Olvera D, Fuller SM, Kelly JP, Graeve OA, Schwarz EM et al. (2014) 3D printing of composite calcium phosphate and collagen scaffolds for bone regeneration. Biomaterials 35, 4026-4034.

25. Do AV, Khorsand B, Geary SM, Salem AK (2015) 3D printing of scaffolds for tissue regeneration applications. Adv Healthc Mater 4, 1742-1762.

26. Wu Z, Su X, Xu Y, Kong B, Sun W, Mi S (2016) Bioprinting three-dimensional cell-laden tissue constructs with controllable degradation. Sci Rep 6, 24474

27. Ozbolat IT, Hospodiuk M (2016) Current advances and future perspectives in extrusionbased bioprinting. Biomaterials 76, 321-343.

28. Trombetta R, Inzana JA, Schwarz EM, Kates SL, Awad HA (2017) 3D printing of calcium phosphate ceramics for bone tissue engineering and drug delivery. Ann Biomed Eng 45, 23-44.

29. Keul C, Stawarczyk B, Erdelt KJ, Beuer F, Edelhoff D, Guth JF (2014) Fit of 4-unit fdps made of zirconia and CoCr-alloy after chairside and labside digitalization--a laboratory study. Dent Mater 30, 400-407.

30. An S, Kim S, Choi H, Lee JH, Moon HS (2014) Evaluating the marginal fit of zirconia copings with digital impressions with an intraoral digital scanner. J Prosthet Dent 112 , 1171-1175.

31. Bertolini Mde M, Kempen J, Lourenco EJ, Telles Dde M (2014) The use of CAD/CAM technology to fabricate a custom ceramic implant abutment: a clinical report. J Prosthet Dent 111,362-366.

32. Huttig F, Keitel JP, Prutscher A, Spintzyk S, Klink A (2017) Fixed dental prostheses and single-tooth crowns based on ceria-stabilized tetragonal zirconia/alumina nanocomposite frameworks: outcome after 2 years in a clinical trial. Int J Prosthodont 30, 461-464.

33. Cenci SN, Gontarsky IA, Moro MG, Pinheiro LOB, Buhrer Samra AP (2017) Anterosuperior rehabilitation with metal-free fixed prosthesis based on zirconia. Eur J Dent 11 , 253-257.

34. Naveau A, Rignon-Bret C, Wulfman C (2019) Zirconia abutments in the anterior region: a systematic review of mechanical and esthetic outcomes. J Prosthet Dent 121, 775-781.

35. Jang Y, Sim JY, Park JK, Kim WC, Kim HY, Kim JH (2018) Evaluation of the marginal and internal fit of a single crown fabricated based on a three-dimensional printed model. J Adv Prosthodont 10, 367-373.

36. Sim JY, Jang Y, Kim WC, Kim HY, Lee DH, Kim JH (2019) Comparing the accuracy (trueness and precision) of models of fixed dental prostheses fabricated by digital and conventional workflows. J Prosthodont Res 63, 25-30.

37. Choi JW, Ahn JJ, Son K, Huh JB (2019) Three-dimensional evaluation on accuracy of conventional and milled gypsum models and 3D printed photopolymer models. Materials (Basel) 12, 3499.

38. Wang W, Yu H, Liu Y, Jiang X, Gao B (2019) Trueness analysis of zirconia crowns fabricated with 3-dimensional printing. J Prosthet Dent 121, 285-291.

39. Li R, Wang Y, Hu M, Wang Y, Xv Y, Liu Y et al. (2019) Strength and adaptation of stereolithography-fabricated zirconia dental crowns: an in vitro study. Int J Prosthodont 32, 439-443.

40. Chang HS, Peng YT, Hung WL, Hsu ML (2019) Evaluation of marginal adaptation of CoCr-Mo metal crowns fabricated by traditional method and computer-aided technologies. J Dent Sci 14, 288-294.

41. V Harish, Ali S. A. Mohamed, N Jagadesan, Ifthikar Mohamed, Senthil Siva, Basak Debasish et al. (2014) Evaluation of internal and marginal fit of two metal ceramic system - in vitro study. J Clin Diagn Res 8, ZC53- ZC56.

42. Sundar MK, Chikmagalur SB, Pasha F (2014) Marginal fit and microleakage of cast and metal laser sintered copings--an in vitro study. J Prosthodont Res 58, 252-258.

43. Park JK, Lee WS, Kim HY, Kim WC, Kim JH (2015) Accuracy evaluation of metal copings fabricated by computer-aided milling and direct metal laser sintering systems. J Adv Prosthodont 7, 122-128.

44. Huang Z, Zhang L, Zhu J, Zhao Y, Zhang X (2015) Clinical marginal and internal fit of crowns fabricated using different CAD/CAM technologies. J Prosthodont 24, 291-295.

45. Ates SM, Yesil Duymus Z (2016) Influence of tooth preparation design on fitting accuracy of CAD-CAM based restorations. J Esthet Restor Dent 28, 238-246.

46. Gunsoy S, Ulusoy M (2016) Evaluation of marginal/internal fit of chrome-cobalt crowns: direct laser metal sintering versus computer-aided design and computer-aided manufacturing. Niger J Clin Pract 19, 636-644.

47. Dahl BE, Ronold HJ, Dahl JE (2017) Internal fit of single crowns produced by CAD-CAM and lost-wax metal casting technique assessed by the triple-scan protocol. J Prosthet Dent $117,400-404$.

48. Lovgren N, Roxner R, Klemendz S, Larsson C (2017) Effect of production method on surface roughness, marginal and internal fit, and retention of cobalt-chromium single crowns. J Prosthet Dent 118, 95-101.

49. Kim KB, Kim WC, Kim HY, Kim JH (2013) An evaluation of marginal fit of three-unit fixed dental prostheses fabricated by direct metal laser sintering system. Dent Mater 29, e91-e96.

50. Nesse H, Ulstein DM, Vaage MM, Oilo M (2015) Internal and marginal fit of cobaltchromium fixed dental prostheses fabricated with 3 different techniques. J Prosthet Dent $114,686-692$

51. Revilla-Leon M, Olea-Vielba M, Esteso-Saiz A, Martinez-Klemm I, Ozcan M (2018) Marginal and internal gap of handmade, milled and 3D printed additive manufactured patterns for pressed lithium disilicate onlay restorations. Eur J Prosthodont Restor Dent 26, 31-38.

52. Khaledi AA, Farzin M, Akhlaghian M, Pardis S, Mir N (2020) Evaluation of the marginal fit of metal copings fabricated by using 3 different CAD-CAM techniques: milling, stereo- 
lithography, and 3D wax printer. J Prosthet Dent 124, 81-86.

53. Lee WS, Lee DH, Lee KB (2017) Evaluation of internal fit of interim crown fabricated with CAD/CAM milling and 3D printing system. J Adv Prosthodont 9, 265-270.

54. Mai HN, Lee KB, Lee DH (2017) Fit of interim crowns fabricated using photopolymerjetting 3D printing. J Prosthet Dent 118, 208-215.

55. Alharbi N, Alharbi S, Cuijpers V, Osman RB, Wismeijer D (2018) Three-dimensional evaluation of marginal and internal fit of 3D-printed interim restorations fabricated on different finish line designs. J Prosthodont Res 62, 218-226.

56. Molinero-Mourelle P, Canals S, Gomez-Polo M, Sola-Ruiz MF, Del Rio Highsmith J, Vinuela AC (2018) Polylactic acid as a material for three-dimensional printing of provisional restorations. Int J Prosthodont 31, 349-350.

57. Tahayeri A, Morgan M, Fugolin AP, Bompolaki D, Athirasala A, Pfeifer CS et al. (2018) 3D printed versus conventionally cured provisional crown and bridge dental materials. Dent Mater 34, 192-200.

58. Chaturvedi S, Alqahtani NM, Addas MK, Alfarsi MA (2020) Marginal and internal fit of provisional crowns fabricated using $3 \mathrm{D}$ printing technology. Technol Health Care 6, 635642.

59. Chen H, Li H, Zhao Y, Zhang X, Wang Y, Lyu P (2019) Adaptation of removable partial denture frameworks fabricated by selective laser melting. J Prosthet Dent 122, 316-324.
60. Tasaka A, Shimizu T, Kato Y, Okano H, Ida Y, Higuchi S et al. (2020) Accuracy of removable partial denture framework fabricated by casting with a $3 \mathrm{D}$ printed pattern and selective laser sintering. J Prosthodont Res 64, 224-230.

61. Tasaka A, Matsunaga S, Odaka K, Ishizaki K, Ueda T, Abe S et al. (2019) Accuracy and retention of denture base fabricated by heat curing and additive manufacturing. J Prosthodont Res 63, 85-89.

62. Choi JJE, Uy CE, Plaksina P, Ramani RS, Ganjigatti R, Waddell JN (2020) Bond strength of denture teeth to heat-cured, $\mathrm{CAD} / \mathrm{CAM}$ and $3 \mathrm{D}$ printed denture acrylics. J Prosthodont 29, 415-421.

63. Liu Y, Di P, Zhao Y, Hao Q, Tian J, Cui H (2019) Accuracy of multi-implant impressions using 3d-printing custom trays and splinting versus conventional techniques for complete arches. Int J Oral Maxillofac Implants 34, 1007-1014.

64. Deng K, Chen H, Li R, Li L, Wang Y, Zhou Y et al. (2019) Clinical evaluation of tissue stops on 3D-printed custom trays. Sci Rep 9, 1807.

65. Xu Y, Huettig F, Schille C, Schweizer E, Geis-Gerstorfer J, Spintzyk S (2020) Peel bond strength between $3 \mathrm{D}$ printing tray materials and elastomeric impression/adhesive systems: A laboratory study. Dent Mater 36, e241-e254.

66. Sun Y, Chen H, Li H, Deng K, Zhao T, Wang Y et al. (2017) Clinical evaluation of final impressions from three-dimensional printed custom trays. Sci Rep 7, 14958. 